\title{
Dwa nieznane listy Witkacego do Kazimierza Twardowskiego
}

(opracował Tomasz Pawlak)

Sztuka Edycji 1/2016

ISSN 2084-7963 (print)

ISSN 2391-7903 (online)

s. $103-110$
Listy Stanisława Ignacego Witkiewicza do profesora filozofii, założyciela szkoły lwowsko-warszawskiej, Kazimierza Twardowskiego ${ }^{1}$, zostały opublikowane w 1988 roku$^{2}$, a następnie w 2013 roku - w nowym opracowaniu³ . Trzy listy z lat 1921-1922 dotyczyły prośby Witkacego o przeczytanie rękopisu jego głównej pracy filozoficznej ${ }^{4}$ - zależało mu na ocenie mogoła ${ }^{5}$ filozofii (do którego napisał, nie znając go osobiście) oraz zapewne na jego rekomendacji do druku w którymś z wydawnictw lub czasopism. Twardowski jednak niezbyt chętnie podejmował się recenzowania nadsyłanych tekstów, tłumacząc się brakiem czasu. Mimo to wysłał Witkacemu swoją książkę, której ten nie mógł zdobyć, a Witkiewicz posłał mu m.in. swoje wydane Nowe formy $w$ malarstwie oraz Szkice estetyczne. Kolejny zachowany list pochodził już z grudnia 1936 roku i dotyczył druku streszczenia odczytu wygłoszonego przez Witkacego 7 grudnia 1936 roku na posiedzeniu Warszawskiego Towarzystwa Filozoficznego. Twardowski musiał się o to streszczenie dopominać, ponieważ Witkacy pi-

${ }^{1}$ Kazimierz Jerzy Adolf Twardowski (1866-1938) - filozof, psycholog i pedagog. Założyciel Polskiego Towarzystwa Filozoficznego, które od 1911 roku wydawało „Ruch Filozoficzny” pod jego redakcja. Od 1911 roku członek Akademii Umiejętności. Zmarł 11 lutego 1938 roku w Milanówku, spoczywa na cmentarzu Łyczakowskim we Lwowie.

${ }^{2}$ R. Jadczak, Listy S. I. Witkiewicza do Kazimierza Twardowskiego, „Przegląd Humanistyczny” 1988, nr 11/12, s. 157-161. O ciekawej pomyłce edytorskiej związanej z tym opracowaniem zob. T. Pawlak, Czyściec edytora w prezentowanym numerze "Sztuki Edycji”.

S. I. Witkiewicz, Dzieła zebrane, t. 17: Listy I, oprac. i przypisami opatrzył T. Pawlak, Warszawa 2013, s. 757-771.

${ }^{4}$ Pojęcia i twierdzenia implikowane przez pojęcie Istnienia 1917-1932, Warszawa 1935, Kasa im. J. Mianowskiego. Zob. S. I. Witkiewicz, Dzieła zebrane, t. 13: „Pojęcia i twierdzenia implikowane przez pojęcie Istnienia” i inne pisma filozoficzne (1902-1932), oprac. B. Michalski, Warszawa 2002

${ }^{5}$ Mogoł - tak Witkiewicz, posługując się terminem z historii Indii, określał wielkie autorytety w dziedzinie nauki. 
sał do Romana Ingardena, że posłał autoreferat na osobistą prośbę Twardowskiego ${ }^{6}$.

Autoreferat ukazał się ostatecznie w „Ruchu Filozoficznym” w 1938 roku?

List z grudnia 1936 roku kończył znaną korespondencję Witkiewicza z Twardowskim.

Podczas pracy nad listami Witkacego do innych niż żona adresatów (w ramach edycji Dziet zebranych Stanisława Ignacego Witkiewicza) niżej podpisany odkrył, że dwa listy identyfikowane dotychczas jako adresowane do profesora Kazimierza Ajdukiewicza ${ }^{8}$ są w istocie listami do Twardowskiego z 1937 roku!

Ustalenie, że prof. Twardowski jest adresatem listów, okazało się niezwykle trudne, nie zachowały się bowiem koperty z adresami, a listy zawierają zwroty grzecznościowe „Wielce Szanowny Panie Profesorze” - co mogło dotyczyć wielu osób (choć już nie Romana Ingardena, który w tym czasie był tytułowany przez Witkacego „Szanownym i Kochanym Profesorem"). Dodatkowo treść listów (dotyczących głównie publikowania artykułów Witkiewicza) nie ułatwiała właściwej identyfikacji adresata, ponieważ zarówno Twardowski, jak i Ajdukiewicz byli redaktorami pism filozoficznych. Ponadto Ajdukiewicz był uczniem i zięciem Twardowskiego, a po II wojnie światowej osiadł w Poznaniu (listy miały pochodzić właśnie z Poznania), co komplikowało jednoznaczną interpretację.

Pomocą dla edytora były listy Witkiewicza pisane po zjeździe filozoficznym w Krakowie we wrześniu 1936 roku oraz list do Twardowskiego z grudnia 1936 roku. Podczas zjazdu Witkacy poznał Ajdukiewicza osobiście: „Więc mój odczyt ogólnie się podobał i dyskusja nie była tak zła, jak myślałem. Największy polski wiedeńczyk Ajdukiewicz ze Lwowa zainteresował się, wziął rękopis i dał mi 2 swoje broszurki”10. Kilka dni później uściślił: „Ajdukiewicz wyraził uznanie za » łamanie « się z trudnymi zadaniami i dla zakresu mojej lektury. Wziął rękopis" ${ }^{11}$. Biorąc pod uwagę ów fakt spotkania z Ajdukiewiczem, trudno było zrozumieć, że w liście z maja 1937 roku, rzekomo do niego pisanym, mogłyby się znaleźć zdania: „Dziękuję też za pozwolenie odwiedzenia Pana we Lwowie, z czego nie omieszkam skorzystać, jak tylko tam się dostanę. Zawsze o tym marzyłem, aby poznać Pana osobiście [wyróżnienie - T. P.] i umiem ocenić zaszczyt, który mnie spotkał”. Wiadomo zaś, że właśnie na osobistym spotkaniu Twardowskiego zależało Witkacemu, o czym ten pisał w liście z 12 grudnia 1936 roku: „Bardzo pragnąłbym móc być Sz. Panu Profesorowi przedstawionym. Czy mogę liczyć na to, że Pan nie odmówi mi tego zaszczytu

${ }^{6}$ „....] na żądanie samego Twardowskiego przesłałem" - list 70 (z 23 marca 1938 roku) do Ingardena, podaję według opracowania T. Pawlaka z: S. I. Witkiewicz, Dzieła zebrane, t. 18: Listy II, wol. 2, oprac. i przypisami opatrzyli J. Degler, T. Pawlak i S. Okołowicz (w przygotowaniu).

${ }^{7}$ Autoreferat odczytu O niesamowystarczalności czystego pogladu fizykalnego był drukowany w „Ruchu Filozoficznym” 1936-1938, t. 14, nr 1/3, s. 142b-144. Zob. przedruk w: S. I. Witkiewicz, Dzieła zebrane, t. 15: „Nauki ścisłe a filozofia” i inne pisma filozoficzne (1933-1939), oprac. M. Dombrowski i M. Bizior-Dombrowska, Warszawa 2014, s. 227-268 (O zjawiskowości tzw. przedmiotu rzeczywistego i fizykalnego jako jego części i o obserwatorze w równaniach fizyki, czyli o niesamowystarczalności czystego poglądu fizykalnego).

${ }^{8}$ Kazimierz Ajdukiewicz (1890-1963) - logik i filozof. Uczeń Kazimierza Twardowskiego i Jana Łukasiewicza na Uniwersytecie we Lwowie. Po doktoracie kontynuował studia w Getyndze, gdzie słuchał m.in. wykładów Edmunda Husserla i matematyka Davida Hilberta. W 1920 roku ożenił się z Marią Twardowską, córką prof. Twardowskiego. W latach 1925-1928 był profesorem Uniwersytetu Warszawskiego, a następnie Uniwersytetu Jana Kazimierza we Lwowie. Współpracował z filozofami z Koła Wiedeńskiego. Po 1945 roku profesor uniwersytetu w Poznaniu i jego rektor (1948-1952), redaktor naczelny „Studia Logica” (1954-1963), profesor Uniwersytetu Warszawskiego (1955-1961).

${ }^{9}$ Listy początkowo uznane za zaginione (zachowały się ich kserokopie z adnotacja, że pochodzą z Instytutu Filozofii Uniwersytetu im. Adama Mickiewicza w Poznaniu) zostały szczęśliwie odnalezione w zbiorach PTF w Poznaniu. Więcej na ten temat zob. T. Pawlak, Czyściec edytora.

${ }^{10}$ S. I. Witkiewicz, Dzieła zebrane, t. 22: Listy do żony (1936-1939), przygotowała do druku A. Micińska, oprac. i przypisami opatrzył J. Degler, Warszawa 2012, list 1040 (z 27 września 1936 roku), s. 81. Wiedeńczyk - zwolennik Koła Wiedeńskiego, grupy filozofów, matematyków, logików i fizyków z Wiednia, którzy zwalczali metafizykę, sprowadzając filozofię do analizy języka nauki.

${ }^{11}$ S. I. Witkiewicz, Dzieła zebrane, t. 22: Listy do żony (1936-1939), list 1042 (z 30 września 1936 roku), s. 83. Por. z Listów do Comeliusa: „Nawet prof. Ajdukiewicz, najwybitniejszy reprezentant Koła Wiedeńskiego w Polsce, zażądał ode mnie rękopisu i wypowiedział killka komplementów o rozległości moich lektur". S. I. Witkiewicz, Dzieła zebrane, t. 18: Listy Il, wol. 2 , list z 4 października 1936 roku. 
i przyjemności, o ile byłbym we Lwowie?”12. Co więcej, w liście do Romana Ingardena, który pośredniczył w kontaktach Witkacego z Twardowskim i Ajdukiewiczem, znajduje się taki passus: „Pisałem do Ajdukiewicza i posłałem mu broszurkę Kotarbeusza ${ }^{13}$ i moją, prosząc, aby rękopis odczytu na zjeździe wręczył Panu - ale nie wiem, czy to wykonał, wicie, haj! Twardowskiemu posłałem streszczenie odczytu z Tow[arzystwa] Fil[ozoficznego] dla »Ruchu « (sam chciał), ale nie wiem, czy to wydrukuje"14. I chociaż znaleźć tu można potwierdzenie, że Witkiewicz pisał do Ajdukiewicza (kolejny mylny trop dla edytora), to jednak zdanie to koresponduje z informacją w liście datowanym na 2 maja 1937 roku: „Nie wiem, czy Pan Profesor otrzymał streszczenie odczytu mojego z Tow[arzystwa] Fil[ozoficznego] w Warszawie, które zaraz na polecenie Jego wysłałem". Witkiewicz także pośrednio wskazuje Twardowskiego, gdy pisze: „Po prostu nie zrozumiałem, że chodzi o »Studia «, a nie o »Ruch «". Redaktorem „Ruchu Filozoficznego” był Kazimierz Twardowski, „Studia Philosophica” redagowali Kazimierz Ajdukiewicz, Roman Ingarden i Kazimierz Twardowski...

Rzecz właściwie przesądził zachowany maszynopis odpowiedzi Twardowskiego do Witkiewicza, w którym profesor lwowski sumituje się, że nie udzielił odpowiedzi na list z 12 grudnia, wzmiankując jednocześnie, że udziela odpowiedzi na obydwa w maju.

I tak, dzięki dogłębnej edytorskiej analizie i znajomości korespondencji Witkiewicza, listy do Ajdukiewicza stały się listami do Twardowskiego.

1.

[Zakopane] 2 V 1937

Wielce Szanowny Panie Profesorze,

Pisał mi prof. Ingarden, że Pan Profesor był łaskaw polecić mi zrobienie krótkiego autoreferatu z mojego tzw. „główniaka” (polska nazwa na „hauptwerk”, którą lansuję). Ponieważ 5 jednocześnie przysłał mi Metallmann swoją recenzję, w której znajduję świetne wprost streszczenie, więc przyszło mi na myśl, czy odpowiadając Metallmannowi i uzupełniając według mnie braki jego krytyki i uznając streszczenie za zasadniczo zgodne z moim na mój "główniak" poglądem, nie zastąpić taką odpowiedzią mego własnego streszczenia.

O ile Pan Profesor zgodziłby się na tę kombinację, byłoby to o tyle dobrze dla mnie,

10 że załatwiłbym przy tym polemikę, a jestem dość zapalonym polemistą. $\mathrm{O}$ ile nie, przygotuję streszczenie w niedługim czasie. Nie wiem, czy Pan Profesor otrzymał streszczenie odczytu mojego z Tow[arzystwa] Fil[ozoficznego] w Warszawie, które zaraz na polecenie Jego wysłałem.

Oczekując dalszych rozporządzeń, łączę wyrazy głębokiej czci i dziękuję raz jeszcze.

Zakopane, 3

Antałówka, Dom Witkiewiczów

\footnotetext{
${ }^{12}$ S. I. Witkiewicz, Dzieła zebrane, t. 17: Listy I, Listy do Twardowskiego, list 4, s. 771

${ }^{13}$ Kotarbeusz - Tadeusz Kotarbiński (1886-1981), filozof, logik, prakseolog.

${ }^{14}$ S. I. Witkiewicz, Dzieła zebrane, t. 18: Listy II, wol. 2, Listy do Ingardena, list 44 (z 18 lutego 1937 roku).
} 
Objaśnienia

12 V 1937 - na górze strony, inną ręką, adnotacje zapewne dokonane w redakcji „Studia Philisophica”: „L [list?]: 116/37 wpł[ynął] 6 V 37"

4 hauptwerk - (niem.), główne dzieło

5 Metallmann - Joachim Metallmann (1889-1942), filozof nauk przyrodniczych, metodolog, profesor UJ

8 nie zastąpić taką odpowiedzią mego własnego streszczenia - J. Metallmann, [rec.] S. I .Witkiewicz, Pojęcia i twierdzenia implikowane przez pojęcie Istnienia, „Ruch Filozoficzny” 1936-1938, t. 14, z. 1-3, s. 50-53; przedruk w: S. I. Witkiewicz, Dzieła zebrane, t. 13: „Pojęcia i twierdzenia implikowane przez pojęcie Istnienia” i inne pisma filozoficzne (1902-1932), oprac. B. Michalski, Warszawa 2002, s. 418-423. Replika S. I. Witkiewicza pt. Odpowiedź na krytykę mego „główniaka” przez Joachima Metallmanna (W ostatnim numerze „Ruchu Filozoficznego") wyszła ostatecznie w „Kwartalniku Filozoficznym” 1939 [1946], t. 16, z. 1, s. 78-83; przedruk w: S. I. Witkiewicz, Dzieła zebrane, t. 13: „Pojęcia i twierdzenia implikowane przez pojęcie Istnienia" i inne pisma filozoficzne (1902-1932), s. 424-429.

10-11 przygotuję streszczenie w niedługim czasie - 4 maja 1937 roku Witkiewicz pisał do Ingardena: „Posłałem Twardowskiemu odpowiedź Metallmannowi, z tym że wobec tego, że streszczenie (główniaka) M[etallmanna] jest idealne i wątpię, czy lepsze zrobię, aby zechciał uznać je za uznane za takowe przeze mnie, a polemikę umieścił w postaci »dopełnienia« do streszczenia w pełni endorsowanego (podpisanego) przeze mnie. Oryginalny pomysł. Jeśli nie, wykonam streszczenie zaraz". S. I. Witkiewicz, Listy do Ingardena, w: idem, Dzieła zebrane, t. 18: Listy II, wol. 2, oprac. i przypisami opatrzyli J. Degler, T. Pawlak i S. Okołowicz (w przygotowaniu), list 50. Dnia 2 maja 1937 roku Witkacy pisał do żony: „Dziś skończyłem odp[owiedź] Metallmannowi”. Idem, Dzieła zebrane, t. 22: Listy do żony (1936-1939), przygotowała do druku A. Micińska, oprac. i przypisami opatrzył J. Degler, Warszawa 2012, list 1084, s. 121.

12 odczytu mojego z Tow[arzystwa] Fil[ozoficznego] w Warszawie - na 422. plenarnym posiedzeniu naukowym Warszaw skiego Towarzystwa Filozoficznego 7 grudnia 1936 roku Witkiewicz wygłosił odczyt O zjawiskowości tzw. przedmiotu rzeczywistego i fizykalnego jako jego części i o obsenwatorze w równaniach fizyki, czyli o niesamowystarczalności czystego poglądu fizykalnego. Witkacy powtórzył ten odczyt 20 maja 1937 roku w Towarzystwie Filozoficznym w Krakowie.

[Odpowiedź Kazimierza Twardowskiego na list z 2 V 1937, maszynopis]

\section{Szanowny Panie!}

Lwów, dn. 14 maja 1937

Bardzo się nieładnie spisałem, żem dotąd nie podziękował Szanownemu Panu za jego list z 12 grudnia z[eszłego] r. i nie podziękował za przysłany mi autoreferat. A chociaż o tym obowiązku swoim pamiętałem, dopiero list Szanownego Pana z 2 bm. stał się dostatecznym bodźcem do jego spełnienia. Odpisuję tedy na oba listy razem w porządku chronologicznym.

Przysłany mi autoreferat jest co prawda ponad zwykłą miarę autoreferatów ruchowych obszerny; mimo to postanowiłem go w „Ruchu Filozoficznym” wydrukować; proszę jednak o pewne wyjaśnienie. Na str. 4 mianowicie znajduje się ustęp, który zawiera w sobie pewne załamanie stylistyczne. Ustęp ten w całości brzmi:

Pomijając już to, że wnętrze ostatecznostki fizykalnej jest w fizykalnym znaczeniu absolutną tajemnicą, to znaczy jest ona już na dalsze elementy nierozkładalna, i pomijając niepoglądowość pewnych utworów i wielkości dzisiejszej fizyki, co by implikowało, że realnie-zjawiskowe rzeczy ( $\mathrm{tz}[\mathrm{n}]$. takie, którym zjawiskowości coś realnego, byt sam w sobie i dla siebie odpowiada), składają się z elementów urojonych. Fizyka nie może, jak żaden zresztą pogląd, zdać sprawy z aktualnej nieskończoności w istnieniu tak z małości, jak i z wielkości. 
Rzecz przesądził zachowany maszynopis odpowiedzi Twardowskiego do Witkiewicza
Otóż brak mi tutaj po słowach „składają się z elementów urojonych” zakończenia zdania; proszę tedy uprzejmie o jego uzupełnienie.

Co się tyczy sprawy autoreferatu książki Szanownego Pana dla „Studia Philosophica”, rozmiary jego nie mogą przekraczać 1000 słów. Sposób jego konstrukcji jest dla nas obojętny; zasadą niewzruszoną jednak jest, by autoreferat nie zawierał nic ponad referowaną pracę i by nie pomijał żadnej naprawdę i niewątpliwie najistotniejszej części jej wywodów.

Autoreferat ma być jednym słowem jak najwierniejszą kopią (oczywiście znacznie zmniejszoną) oryginału. Nie mógłby tedy autoreferat Szanownego Pana zawierać jakiejkolwiek reakcji na krytykę p. Metallmanna; nie ma natomiast żadnej przeszkody, ażeby Szanowny Pan jako autoreferat do „Studia Philosophica” podał ,świetne wprost streszczenie" p. Metallmanna, o ile tenże na to się zgodzi. Pozostawiam to najzupełniej Szanownemu Panu.

List swój z 12 XII zr. kończy Szanowny Pan wyrażeniem pragnienia zobaczenia się ze mną. Będzie mi oczywiście rzeczą bardzo miłą, jeżeli będę mógł Szanownego Pana przy okazji u siebie powitać. Zdrowie moje co prawda nie bardzo jest w porządku, a raczej

35 jest bardzo w nieporządku, sądzę jednak, że okoliczność ta nie stanie Szanownemu Panu w przeszkodzie do odwiedzenia mnie. Proszę tedy, o ile Szanowny Pan będzie we Lwowie, porozumieć się ze mną telefonicznie (nr 265-64).

Zwracając z podziękowaniem „odpowiedź” na krytykę p. Metallmanna, łączę wyrazy prawdziwego poważania.

\section{Objaśnienia}

1 Odpowiedź Kazimierza Twardowskiego na list z 2 V 1937, maszynopis - oryginał w zbiorach Polskiego Towarzystwa Filozoficznego, Oddział w Poznaniu. Maszynopis jest niepodpisany, widnieje na nim pisane odręcznie nazwisko: Witkiewicz - dwa razy, a także przytwierdzone w lewym górnym rogu potwierdzenie nadania listu ze stemplem pocztowym: Lwów, 15 V 37.

Wielce Szanowny Panie Profesorze,

Serdecznie dziękuję Panu Profesorowi za Jego list tak dla mnie wartościowy, przez to, że Pan się do mnie z pewną życzliwością odnosi. A miałem wrażenie, że moje praca [!]

5 mogą Pana Profesora szokować przez swoją zbyteczną może „intensywność” formy. Dziękuję też za pozwolenie odwiedzenia Pana we Lwowie, z czego nie omieszkam skorzystać, jak tylko tam się dostanę. Zawsze o tym marzyłem, aby poznać Pana osobiście i umiem ocenić zaszczyt, który mnie spotkał. Co do zdania z mojego artykułu, za którego chęć druku mimo rozmiarów nieodpowiednich serdecznie dziękuję, to mnie się zdaje,

10 że staje się ono jasnym, o ile po „elementów urojonych” wstawimy przecinek zamiast punktu i „fizyka” napiszemy małą literą - wtedy do tego przecinka jest (przydługi) wstęp w związku ze słowem „pomijając", a od „fizyki” jest zdanie właściwe. We wtorek 18/V wyjeżdżam do Krakowa, gdzie mam mieć odczyt 20/V w Tow[arzystwie] Filozoficznym, ten sam z ich zezwoleniem, co w Warszawie, z którego właśnie autoreferat Panu Profesorowi sam autoreferat, na moich 5 stron - każda zawiera około 200 słów. Po prostu nie zrozumiałem, że chodzi o „Studia”, a nie o „Ruch”. Jest dla mnie wielkim zaszczytem, że Pan Profesor 
pozwala mi wydrukować moje streszczenia w obu pismach, ponieważ zdanie Pana jest dla mnie niezmiernie cenne, a filozofia najważniejszą rzeczą w moim życiu i to od dawna; zajmuję się nią (z przerwami - wojna i zakorkowanie przez Corneliusa) od $16^{\text {go }}$ roku życia.

Łączę wyrazy głębokiej czci i - jeśli mi wolno się tak wyrazić - sympatii na odległość w związku z listem, i wielkiej wdzięczności.

Stanisław Ignacy Witkiewicz

\section{Zakopane, 3 Antałówka}

PS Nie wiem, czy prof. Ingarden wspominał Panu Profesorowi, że przesłałem mu większą moją pracę o Ludwigu Wittgensteinie. Wedle sił jestem zmuszony choćby dla celów osobistych „walczyć” z Kołem Wiedeńskim. To jest początek.

\section{Objaśnienia}

$1 \quad 16$ V 1937 - u góry strony, inną ręką: 326 - 20.05.1937 (prawdopodobnie data wpływu)

11-12 wtedy do tego przecinka jest (przydługi) wstęp w związku ze słowem „pomijając”, a od "fizyki” jest zdanie właściwe - jest to fragment jednej z wersji streszczenia odczytu O zjawiskowości tzw. przedmiotu rzeczywistego i fizykalnego jako jego części i obserwatorze w równaniach fizyki, czyli o niesamowystarczalności czystego poglądu fizykalnego, która ostatecznie ukazała się w „Ruchu Filozoficznym”. Zob. S. I. Witkiewicz, Dzieła zebrane, t. 17: Listy I, oprac. i przypisami opatrzył T. Pawlak, Warszawa 2013, Listy do Twardowskiego, list 4, s. 771, przypis 2. O istniejących wariantach tego tekstu zob. idem, Dzieła zebrane, t. 15: „Nauki ścisłe a filozofia” i inne pisma filozoficzne (1933-1939), oprac. M. Dombrowski i M. Bizior-Dombrowska, Warszawa 2014, s. 740. W wydaniu w ramach edycji Dzieł zebranych nie została uwzględniona wersja podana w liście do Twardowskiego. Karta rękopisu z tym zdaniem znajduje się w zbiorach Biblioteki Jagiellońskiej, sygn. Rkp 9467 IV, O zjawiskowości tzw. przedmiotu rzeczywistego i fizykalnego jako jego części i o obserwatorze w równaniach fizyki, czyli o niesamowystarczalności czystego poglądu fizykalnego [Rękopis], k. 43 (numeracja ciągła BJ). Zgodnie z propozycją i autokorektą Witkiewicza zdanie powinno brzmieć: „Pomijając już to, że wnętrze ostatecznostki fizykalnej jest (w fizykalnym znaczeniu) absolutną tajemnica (tzn. jest ona już na dalsze elementy nierozkładalna) i pomijając niepogladowość pewnych utworów i wielkości dzisiejszej fizyki, co by implikowało, że realnie-zjawiskowe rzeczy (tzn. takie, których zjawiskowości coś realnego, byt sam w sobie i dla siebie, odpowiada), składają się z elementów urojonych, fizyka nie może, jak żaden zresztą pogląd, zdać sprawy z aktualnej nieskończoności w Istnieniu tak w małości, jak i w wielkości". Dziękuję Maciejowi Dombrowskiemu za pomoc w identyfikacji tej strony rękopisu.

13 gdzie mam mieć odczyt 20N w Tow[arzystwie] Filozoficznym - 20 maja (w literaturze funkcjonuje błędna data 21 maja) 1937 roku w krakowskim Towarzystwie Filozoficznym Witkacy powtórzył odczyt O zjawiskowości tzw. przedmiotu rzeczywistego i fizykalnego jako jego części i obserwatorze w równaniach fizyki, czyli o niesamowystarczalności czystego pogladu fizykalnego, który wygłosił 7 grudnia 1936 w Towarzystwie Filozoficznym Warszawskim. Krakowski „Czas” zapowiadał w czwartkowym wydaniu z 20 maja: „Dzisiaj, dnia 20 bm. o godz. 6 wieczorem w sali Seminarium filozof. Uniw. Jagiell. (ul. Józefa Piłsudskiego 4, piętro I) Stanisław Ignacy Witkiewicz wygłosi odczyt pt. O niesamowystarczalności czystego poglądu fizykalnego. Goście mile widziani”. „Czas” 1937, nr 136, s. 8 (Kronika Krakowa). Dnia 15 maja Witkiewicz pisał do żony: „Miałem wiadomość od Gieleckiego, że mój odczyt w Tow[arzystwie] Fil[ozoficznym] krakowskim ma być o 6tej wiecz. we czwartek". S. I. Witkiewicz, Dzieła zebrane, t. 22: Listy do żony (1936-1939), przygotowała do druku A. Micińska, oprac. i przypisami opatrzył J. Degler, Warszawa 2012, list 1087, s. 124.

17 "Studia” - chodzi o autoreferat główniaka w języku francuskim, opublikowany na łamach pisma "Studia Philosophica” 1937, t. 2, s. 487-489: Les notions et les propositions impliquées par la notion de l'existance (Pojęcia i twierdzenia implikowane przez pojęcie istnienia) - pisownia oryginalna; przedruk w: S. I. Witkiewicz, Dzieła zebrane, t. 13: „Pojęcia i twierdzenia implikowane przez pojęcie Istnienia” i inne pisma filozoficzne (1902-1932), oprac. B. Michalski, Warszawa 2002, s. 432-434. Witkacy pisał do Ingardena 9 czerwca 1937 roku: „Tłum[aczenie] franc[uskie] do "Studia« przesłałem Twardzimierzowi (Twardzi i potem mierzy)". Idem, Dzieła zebrane, t. 18: Listy II, wol. 2 (w przygotowaniu), Listy do Ingardena, list 51. Kazimierz („Twardzimierz”) Twardowski (podobnie jak Ingarden i Ajdukiewicz) był także redaktorem „Studia Philosophica".

26 Wittgensteinie - Ludwig Wittgenstein (1889-1951), filozof austriacki, od 1929 roku profesor Cambridge 
[Odpowiedź Kazimierza Twardowskiego na list z 16 V 1937, maszynopis]

Lwów, dn. 21 maja 1937

Szanowny Panie!

Najuprzejmiej dziękuję za list z 16 bm., którego serdecznym tonem szczerze się ucieszyłem. O sposobie, w jaki odnoszę się do prac filozoficznych Szanownego Pana, pomówimy sobie, gdy uda nam się spotkać się ze sobą; dzisiaj niechaj wystarczy zapewnienie, iż bardzo żałuję, że Szanowny Pan nie znajdował się nigdy wśród członków mego Seminarium. Ale to jest rzecz nie do naprawienia.

Niezrozumiałe zrazu zdanie w przeznaczonym do „Ruchu Filozoficznego” auto-

10 referacie z warszawskiego odczytu Szanownego Pana poprawiłem według wskazówek Szanownego Pana; jest ono teraz zupełnie poprawne i zrozumiałe, chociaż nieco ciężkie.

Obawiam się nieco, że w sprawie autoreferatu, o którym pisałem w liście swoim z 14 bm., i o stosunku tego autoreferatu do autoreferatu dawniej mi przez Szanownego Pana przysłanego, wyraziłem się w liście z 14 maja niezupełnie jasno, tak, iż co do sto-

15 sunku obu autoreferatów mogłoby zajść nieporozumienie. Dlatego zaznaczam: 1) oba autoreferaty są najzupełniej od siebie niezależne, 2) autoreferat odczytu w Warszawskim Towarzystwie Filozoficznym powinien być wyłącznie zwięzłym streszczeniem tego, co Szanowny Pan w odczycie swoim powiedział. Taki jest też autoreferat przysłany mi w grudniu zeszłego roku, 3) autoreferat z głównego Dzieła Szanownego Pana, czyli z Jego

20 "Główniaka”, przeznaczony dla „Studia Philosophica” powinien być zwięzłym streszczeniem tego, co Szanowny Pan w książce swojej powiedział, 4) autoreferat przysłany mi przez Szanownego Pana w grudniu zeszłego roku będzie drukowany w języku polskim dla czytelników polskich; referat przeznaczony do „Studia Philosophica” będzie drukowany po francusku dla czytelników zagranicznych. $\mathrm{O}$ ten to drugi autoreferat prosiłem, by zawierał 1000 słów - sądzę, że wyjaśniłem wszystko należycie. Autoreferat przeznaczony dla „Studia” proszę przysłać pod moim adresem.

Jeśli pamięć mnie nie myli, Prof. Ingarden nie wspomniał mi o pracy Szanownego Pana o Wittgensteinie. Rzecz jasna, że Szanowny Pan, zajmując swoje stanowisko filozoficzne, musi walczyć z Kołem Wiedeńskim.

Łączę wyrazy najwyższego poważania.

\section{Objaśnienia}

1 Odpowiedź Kazimierza Twardowskiego na list z 16 V 1937, maszynopis - oryginał w zbiorach Polskiego Towarzystwa Filozoficznego w Poznaniu. Maszynopis jest niepodpisany, z odręcznie wpisanym pod datą nazwiskiem adresata: Witkiewicz.

Key Words: Stanisław Ignacy Witkiewicz (Witkacy), Kazimierz Twardowski, Kazimierz Ajdukiewicz, letters

Summary: Letters of Stanisław Ignacy Witkiewicz to Kazimierz Twardowski, professor of philosophy were published in 1988 in a monograph by Ryszard Jadczak, and later in 2013 - in a new monograph by the author of materials presented herein in volume 17 of Witkiewicz's Dzieta zebrane. The letter from December 1936 concluded the correspondence between Witkiewicz and 
Twardowski. While working on Witkacy's letters to different addressees, I have discovered that two of the letters, which had been previously identified as addressed to professor Kazimierz Ajdukiewicz, were in fact letters to Twardowski from 1937!

Determining that professor Twardowski is the addressee of the letters turned out to be extremely difficult, as no envelopes with addresses have survived, and the letters contain salutations "Dear Professor"- which could mean many people. In addition, the content of the letters (concerning mostly the publishing of Witkacy's articles) did not make it easier to identify the addressee properly, as both Twardowski and Ajdukiewicz were editors of philosophical journals. What is more, Ajdukiewicz was Twardowski's student and son-in-law, and after World War II he settled in Poznań (the letters were from Poznań), which made unambiguous identification complicated.

What was helpful for the editor were Witkiewicz's letters written after philosophical congress in Cracow in September 1936, and the letter by from December 1936. Thanks to a thorough analysis of Witkiewicz's correspondence, it was possible to determine that what was believed to be letters to Ajdukiewicz was in fact letters to Twardowski.

ㄴ. $\operatorname{sg} 37$

$$
\begin{aligned}
& \text { Nielce favomy Savir Dinfesora: }
\end{aligned}
$$

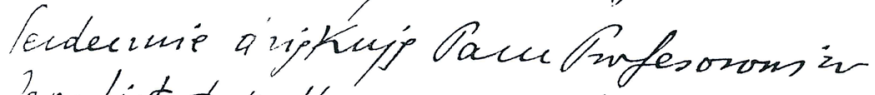

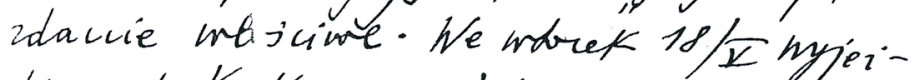
diam do Kw, Kowr, folne mam mier.

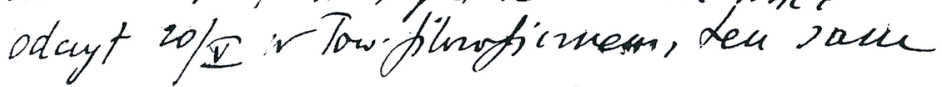

taine autoritenat tain infesoromi hositatem. foceu zoror hyjeidiam do Warsainy polese

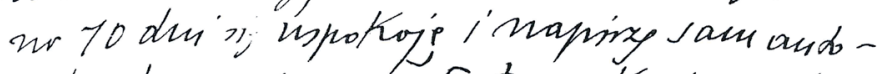
seferat, na moich 5 stou - Koido zakien

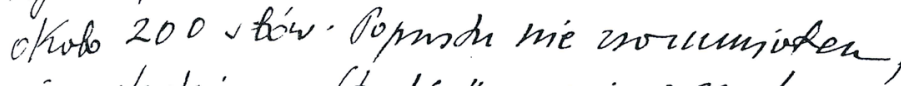
ie chotr". "Sholia" a nie o mcho. Zest dor mie rielfisim zasicutem, ié liau Piofeso in prala mi hryduftomac mije stresicuenia w of nismach poniemai zda vie Paur jest dlo smie nier-

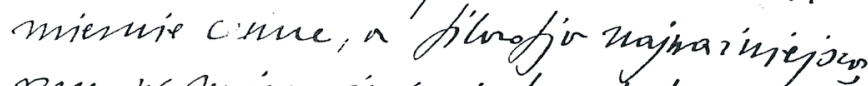
neery w miem iycín, Lo od dawna, zy-

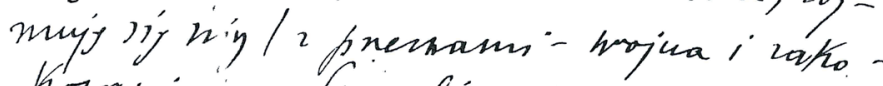
Komxuie inu Comeliusa) od 162 sokm iycía:

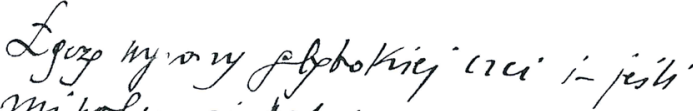

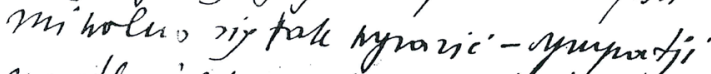

$$
\begin{aligned}
& \text { us odlegisic' w migntan } 2 \text { listem,, } \\
& \text { nielticy adripunotin. }
\end{aligned}
$$

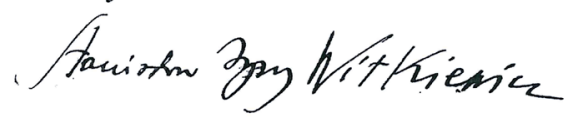

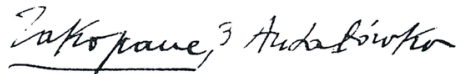

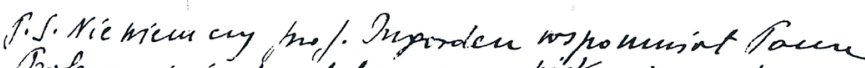

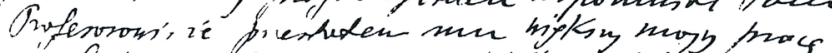

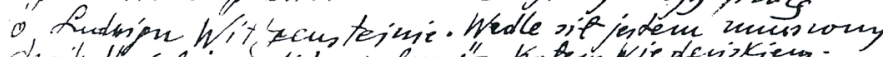

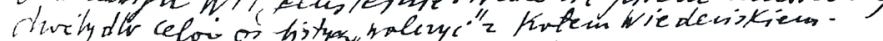
To pest hocryder. 